ORIGINAL

\title{
Prevalence of asthma and wheezes among snow crab workers in western Japan : a cross-sectional study
}

\author{
Masanari Watanabe ${ }^{1}$, Jun Kurai ${ }^{1}$, Hiroyuki Sano², Hiroya Kitano ${ }^{3}$, and Eiji Shimizu ${ }^{1}$ \\ ${ }^{1}$ Department of Respiratory Medicine and Rheumatology, Tottori University Faculty of Medicine, 36-1 Nishi-cho, Yonago, 683-8504, Japan, \\ ${ }^{2}$ Department of Respiratory Medicine and Allergology, Kinki University Faculty of Medicine, 377-2 Ohnohigashi, Osakasayama, 589-0014, \\ Japan, ${ }^{3}$ The Board of Directors, Tottori University, 36-1 Nishi-cho, Yonago, 683-8504, Japan
}

\begin{abstract}
Objectives : Few reports are available concerning the prevalence of asthma among snow crab workers in Japan. The object of this study was to estimate the prevalence of asthma and wheezes among Japanese snow crab workers and their associations with exhaled nitric oxide (FeNO) and YKL-40. Methods : Forty-nine snow crab workers enrolled in this study, which was cross-sectional by design and was conducted using a translated version of the European Community Respiratory Health Survey questionnaire. The levels of FeNO and serum YKL-40 were measured between September and October 2014. Results : The prevalences of current asthma and wheezes were $10.2 \%$ (95\% CI, 3.4 to 22.2 ) and $12.2 \%$ (95\% CI, 4.6 to 24.8 ), respectively. There was no association between these prevalences and the duration of snow crab employment. Six subjects' FeNO levels exceeded 50 ppb, and nine subjects' levels exceeded 25 ppb. Twelve subjects' (25.5\%) serum YKL-40 levels exceeded $77.2 \mathrm{ng} / \mathrm{mL}$, which was 2 standard deviations above the mean for healthy subjects. However, there were no significant relationships among the prevalences for asthma and wheezes, FeNO, and serum YKL-40. Conclusions : This study provides information concerning the prevalences of asthma and wheezes among Japanese snow crab processing workers. J. Med. Invest. 63 : 74-79, February, 2016
\end{abstract}

Keywords : asthma, ECRHS, prevalence, snow crab processing, wheezes

\section{INTRODUCTION}

Occupational asthma $(\mathrm{OA})$ is a substantial cause of occupational lung disease in many industrialized countries $(1,2)$. Its prevalence has been difficult to establish with precision due, in part, to ambiguous definitions and diagnostic criteria, as well as challenging work settings and limited surveillance data. Generally, OA has been implicated in 9 to $15 \%$ of adult asthma cases (3-6). The clinical and pathologic features of OA do not differ from non-occupational asthma. OA investigations have the potential to provide beneficial information about the effects of genetic, environmental, and behavioral interactions in adult onset asthma.

Snow crab harvesting and processing is an important industry in Japan ; however, it is one of the most important causes of OA. It has been estimated that snow crab workers account for approximately $16 \%$ of all OA cases (7-9). The pathophysiology of snow crab $\mathrm{OA}$ is mediated through an immunologic mechanism involving an immunoglobulin E (IgE) -dependent mechanism (9-12). Specific $\mathrm{IgE}$ antibodies to crab meat and cooking water are induced by exposure to the crab proteins in dust, steam, and vapor that are generated by cleaning, steaming, boiling, washing, sawing, or crushing crab in processing plants (9-12). During these activities, crab proteins can become airborne and penetrate an individual's airways. Existing research on OA in general suggests that snow crab OA is likely to be significant $(13,14)$. However, the socioeconomic impacts of snow crab OA have been poorly studied, especially in Japan.

Asthma is characterized by chronic airway inflammation, reversible airway narrowing, and airway hyperresponsiveness (15).

Abbreviations : CI : confidence intervals ; ECRHS : the European Community Respiratory Health Survey ; ELISA : enzyme-linked immunosorbent assay ; FeNO : fractional exhaled nitric oxide ; FVC : forced vital capacity $; \mathrm{FEV}_{1}$ : forced expiratory volume in 1 second ; IgE : immunoglobulin E; OA : Occupational asthma ; SD : standard deviation
Airway eosinophilic inflammation is one characteristic feature. Fractional-exhaled nitric oxide (FeNO) is a new method representing an eosinophilic airway inflammation that significantly correlates with sputum eosinophilia and asthma severity, instead of a sputum eosinophil count that is easily influenced by corticosteroid therapy (16). YKL-40, also called human cartilage glycoprotein39 (HC gp-39), is produced at many cell inflammation sites and is secreted from macrophages and smooth muscle cells (17). In addition to FeNO, YKL-40 is associated with asthma severity, pulmonary function, and airway remodeling $(17,18)$.

In Japan, few studies have estimated the prevalence of asthma and wheezes among snow crab processing workers using a standardized questionnaire. Additionally, recent technological developments have led to improvements in the handicraft production of snow crab processing. The current prevalence of asthma and wheezes among snow crab processing workers may differ from that experienced in the past. To determine the prevalence of asthma among Japanese snow crab processing workers, a cross-sectional study was conducted in Western Japan with a standardized questionnaire. We also measured pulmonary function, the levels of FeNO, and the amount of YKL-40 that replenished according to the diagnosis and severity of asthma.

\section{MATERIALS AND METHODS}

\section{Study design}

The primary outcome variable was the prevalence of asthma and Received for publication September 24, 2015 ; accepted November 13, 2015.

Address correspondence and reprint requests to Masanari Watanabe, M.D., Ph.D., Department of Respiratory Medicine and Rheumatology, Tottori University Faculty of Medicine, 36-1 Nishichou, Yonago 6838504, Japan and Fax : +81-859-38-6539. 
wheezes among Japanese snow crab processing workers. A crosssectional study was conducted using the European Community Respiratory Health Survey (ECRHS) questionnaire. We asked one snow crab processing company located in Sakaiminato City, Japan, to cooperate in this cross-sectional study. This company had 49 employees (15 male and 34 female), and all employees agreed to participate in the study. Door to door surveys were conducted in 2014, from September to October. This study was approved by an institutional ethics committee (Ethics Committee of Tottori University, Approval Number 2061), and all subjects gave their written informed consent before participating.

\section{Questionnaire}

To evaluate asthma symptoms, we asked questions similar to those appearing in the ECRHS. The Japanese version of the onepage ECRHS questionnaire was prepared, and the first page of this originally two-page questionnaire was prepared for a Stage One repeat study $(19,20)$. The validity of the questionnaire was guaranteed by first translating the Japanese version back into English (21). The questionnaire items can be found at http : //www.ecrhs. org. In addition to assessing respiratory health, this questionnaire included demographic questions on age, gender, height, weight, and smoking history.

Whether a patient had ever experienced asthma that was confirmed by a doctor was assessed according to a positive answer to the question : "Have you ever had asthma?" (Q5), which was followed by: "Was this confirmed by a doctor?" (Q5.1). Current presence of asthma was defined according to the following criteria : [1] affirmative responses to Q5 and Q5.1, and [2] an affirmative response to the "Having at least one asthma-related symptom in the last 12 months" item (22). The subject who answered affirmatively to at least one question out of Qs1-4 was considered to have asthmarelated symptoms. If subjects had had asthma-related symptoms in the past that remitted, they were excluded from the current asthma category.

\section{Measurement of pulmonary function and FeNO}

Pulmonary function tests were performed three consecutive times with a dry spirometer (Spiroshift SP-350COPD, Fukuda Denshi, Tokyo, Japan), and the highest values were recorded. The following parameters were measured : forced vital capacity (FVC), forced expiratory volume in 1 second $\left(\mathrm{FEV}_{1}\right)$, and predicted $\mathrm{FEV}_{1} \%$. FeNO was measured using NObreath (Bedfont Scientific, Maidstone, Kent, UK), following American Thoracic Society/European Respiratory Society recommendations (23).

\section{Measurement of $Y K L-40$}

YKL-40 serum concentrations were determined using an enzyme-linked immunosorbent assay (ELISA) kit for human chitinase 3-like 1 immunoassay (R\&D Systems, Minneapolis, MN, USA). Samples were run in triplicate and were read using an automated ELISA reader (Model680, Bio-Rad, Philadelphia, PA, USA).

\section{Statistical analysis}

The results are shown as means \pm standard deviations (SDs). SPSS Statistics software (Japanese ver. 21.0 for Windows ; IBM Japan, Tokyo, Japan) was used for all statistical analysis. The prevalence of current asthma with $95 \%$ confidence intervals (CI) was estimated for all the participants aged 20-69 years. Fisher's exact tests were performed to assess the differences in prevalence between males and females. Differences in YKL-40 and FeNO according to employment duration were analyzed by a Kruskal-Wallis one-way ANOVA. A $t$-test was performed to estimate the difference in YKL-40 between smokers and non-smokers. Associations among YKL-40 and FeNO levels were assessed using linear regression analysis. All quoted $\mathrm{P}$ values are two-sided, and the significance level was set at 0.05 .

\section{RESULT}

Table 1 presents the characteristics of the subjects. The prevalences of current asthma and wheezes were $10.2 \%$ (95\% CI, 3.4 to 22.2 ) and $12.2 \%$ (95\% CI, 4.6 to 24.8 ), respectively (Table 2$)$. None of the subjects were undergoing treatment for asthma or other respiratory diseases. Table 3 shows the prevalence of asthma-related symptoms. Table 4 presents the prevalence of wheezes according to total duration of employment as a snow crab processing worker. There were no statistically significant differences between employment duration in terms of current asthma or wheezes prevalence. Table 5 shows pulmonary functioning according to presence of current asthma and wheezes and the significance was not detected. Table 6 presents pulmonary functioning according to total duration of employment as a snow crab processing worker. There were no statistically significant differences in pulmonary functioning based on employment duration.

Figure 1A shows the relationship between the levels of YKL-40 and the duration of employment. Two samples were missing YKL40 measurements due to blood clotting. The levels of YKL-40 in subjects who had worked in this profession for more than 20 years were significantly higher than those in the $<1$ year- and 1 to 4 -year groups. In contrast, there were no significant differences between smokers and non-smokers (Fig. 1B). Figure 2 shows the levels of

Table 1. Descriptive characteristics of the study population

\begin{tabular}{lrl}
\hline \multicolumn{1}{c}{ Variables } & $\mathrm{n}(\%)$ \\
\hline Gender (male/female) & 49 & $(30.6 / 69.4)$ \\
Mean age (in years) \pm S.D. & 47.73 & \pm 14.51 \\
Smoking history & & \\
$\quad$ Non-smoker & 26 & $(53.1)$ \\
$\quad$ Past smoker & 4 & $(8.2)$ \\
$\quad$ Current smoker & 19 & $(38.8)$
\end{tabular}

Duration of employment as

snow crab worker

$\begin{array}{lrc}<1 \text { year } & 17 & (34.7) \\ \text { 1-4 years } & 11 & (22.4) \\ \text { 5-9 years } & 6 & (12.2) \\ \text { 10-19 years } & 7 & (14.3) \\ \geq 20 & 8 & (16.3) \\ \text { Pulmonary function } & & \\ \text { FVC (L) } & 3.21 & \pm 0.89 \\ \mathrm{FEV}_{1} \%(\%) & 80.92 & \pm 6.54 \\ \text { Predicted } \mathrm{FEV}_{1} \%(\%) & 97.20 & \pm 16.8\end{array}$

Data are shown as the mean \pm S.D., or as numbers with percentages in parentheses (\%).

$\mathrm{FEV}_{1}$ : forced expiratory volume in 1 second $; \mathrm{FEV}_{1} \%$ : ratio of $\mathrm{FEV}_{1}$ to FVC ; FVC : forced vital capacity ; S.D. : standard deviation.

Table 2. Prevalence of current asthma and wheezes

\begin{tabular}{lll}
\hline & Total \\
& $\%(95 \% \mathrm{CI})$ \\
\hline Current asthma & 10.2 & $(3.4-22.2)$ \\
Wheezes & 12.2 & $(4.6-24.8)$ \\
\hline
\end{tabular}

Data are presented as percentages with $95 \% \mathrm{CI}$ in parentheses. $\mathrm{CI}$ : confidence interval. 
Table 3. Prevalence of asthma-related symptoms

\begin{tabular}{lrl}
\hline & \multicolumn{2}{c}{ Total } \\
& $\%(95 \% \mathrm{CI})$ \\
\hline (Q1) Wheezes & 12.2 & $(4.6-24.8)$ \\
(Q1.1) Wheezes with breathlessness & 6.1 & $(1.3-16.9)$ \\
(Q1.2) Wheezes without a cold & 8.2 & $(2.3-19.6)$ \\
(Q2) Waking with chest tightness & 0 & $(0-7.3)$ \\
(Q3) Waking with shortness of breath & 2 & $(0.1-10.9)$ \\
(Q4) Waking with cough & 16.3 & $(7.3-29.7)$ \\
(Q5) Ever had asthma & 12.2 & $(4.6-24.8)$ \\
(Q5.1) Ever had asthma confirmed by a doctor & 12.2 & $(4.6-24.8)$ \\
\hline
\end{tabular}

Data are presented as percentages with $95 \% \mathrm{CI}$ in parentheses. $\mathrm{CI}$ : confidence interval.

Table 4. Prevalence of wheezes by snow crab worker employment duration

\begin{tabular}{|c|c|c|c|c|c|}
\hline \multicolumn{5}{|c|}{ Employment duration as snow crab worker } & \multirow[b]{2}{*}{ P value } \\
\hline $\begin{array}{c}<1 \text { year } \\
\%(95 \% \mathrm{CI})\end{array}$ & $\begin{array}{l}\text { 1-4 years } \\
\%(95 \% \mathrm{CI})\end{array}$ & $\begin{array}{c}\text { 5-9 years } \\
\%(95 \% \mathrm{CI})\end{array}$ & $\begin{array}{l}\text { 10-19 years } \\
\%(95 \% \mathrm{CI})\end{array}$ & $\begin{array}{c}\geq 20 \\
\%(95 \% \mathrm{CI})\end{array}$ & \\
\hline 11.8 (1.5-36.4) & $18.2(2.3-51.8)$ & $0(0-39.3)$ & $28.6(3.7-71)$ & $0(0-31.2)$ & 0.399 \\
\hline
\end{tabular}

Data are presented as percentages with $95 \%$ in parentheses. CI : confidence interval.

Table 5. Pulmonary function in the study population

\begin{tabular}{lcccc}
\hline \multicolumn{1}{c}{ Variables } & $\begin{array}{c}\text { Subjects without } \\
\text { current asthma and } \\
\text { wheezes }(\mathrm{n}=42)\end{array}$ & $\begin{array}{c}\text { Subjects with current } \\
\text { asthma } \\
(\mathrm{n}=5)\end{array}$ & $\begin{array}{c}\text { Subjects with } \\
\text { wheezes }(\mathrm{n}=6)\end{array}$ \\
\hline FVC (L) & $3.21 \quad \pm 0.95$ & $3.30 \pm 0.45$ & $3.10 \pm 0.39$ \\
$\mathrm{FEV}_{1} \%$ (\%) & $80.86 \pm 6.70$ & $81.20 \pm 4.77$ & $80.23 \pm 4.77$ \\
Predicted $\mathrm{FEV}_{1} \%$ (\%) & $96.71 \pm 17.70$ & $97.00 \pm 8.66$ & $80.23 \pm 5.82$ \\
\hline
\end{tabular}

Data are shown as the mean \pm SD. $F V C$ : forced vital capacity ; $\mathrm{FEV}_{1} \%$ : forced expiratory volumes in one second $\left(\mathrm{FEV}_{1}\right)$ and ratio of $\mathrm{FEV}_{1}$ to $\mathrm{FVC}$. $\mathrm{SD}$ : standard deviation.

Table6. Pulmonary function according to snow crab worker employment duration

\begin{tabular}{|c|c|c|c|c|c|c|c|c|c|c|}
\hline \multirow{3}{*}{ Variables } & \multicolumn{9}{|c|}{ Employment duration as snow crab worker } & \multirow{3}{*}{$\frac{\text { P value }}{0.638}$} \\
\hline & $<1$ year & \multicolumn{2}{|c|}{$1-4$ years } & \multicolumn{2}{|c|}{$5-9$ years } & \multicolumn{2}{|c|}{ 10-19 years } & \multicolumn{2}{|c|}{$\geq 20$} & \\
\hline & $3.83 \pm 0.84$ & 2.86 & \pm 0.85 & 2.72 & \pm 0.67 & 3.00 & \pm 0.49 & 2.96 & \pm 0.88 & \\
\hline $\mathrm{FEV}_{1} \%(\%)$ & \pm 5.86 & 81.56 & \pm 7.40 & 84.82 & \pm 5.83 & 81.42 & \pm 5.91 & 76.93 & \pm 7.14 & 0.914 \\
\hline Predicted $\mathrm{FEV}_{1} \%(\%)$ & \pm 13.70 & 89.55 & \pm 14.20 & 96.17 & \pm 12.61 & 102.35 & \pm 13.21 & 97.88 & \pm 28.00 & 0.098 \\
\hline
\end{tabular}

Data are shown as the mean \pm S.D.

$\mathrm{FEV}_{1}$ : forced expiratory volume in 1 second $; \mathrm{FEV}_{1} \%$ : ratio of $\mathrm{FEV}_{1}$ to $\mathrm{FVC} ; \mathrm{FVC}$ : forced vital capacity ; S.D. : standard deviation.

FeNO dividing into employment duration and demonstrates that no significant relationships were found between them. In five subjects who did not experience wheezes over the previous 12 months, FeNO levels exceeded $50 \mathrm{ppb}$. The FeNO levels of one subject who had experienced wheezes within the previous 12 months exceeded $50 \mathrm{ppb}$. In contrast, the FeNO levels of four out of six subjects who had experienced wheezes did not exceed $25 \mathrm{ppb}$. Figure 3 shows the relationship between the levels of YKL-40 and FeNO. No significant associations were found.

\section{DISCUSSION}

Asthma is a serious global health problem affecting all age groups
(24). Its prevalence is increasing in many countries. Certain occupational exposures are associated with asthma. Previous studies of occupational exposures among various groups of workers have suggested that asthma prevalence may be notably high among snow crab processing workers (7-9). However, few reports exist concerning the prevalence of asthma among snow crab processing workers in Japan. As far as we know, this is the first study to estimate the prevalences of asthma and wheezes among Japanese snow crab processing workers using a standard questionnaire. The prevalences of current asthma and wheezes among Japanese snow crab processing workers were $10.2 \%$ (95\% CI, 3.4 to 22.2$)$ and $12.2 \%$ (95\% CI, 4.6 to 24.8), respectively. These data provide fundamental information concerning respiratory and public health among Japan's harvesting and processing workers. 

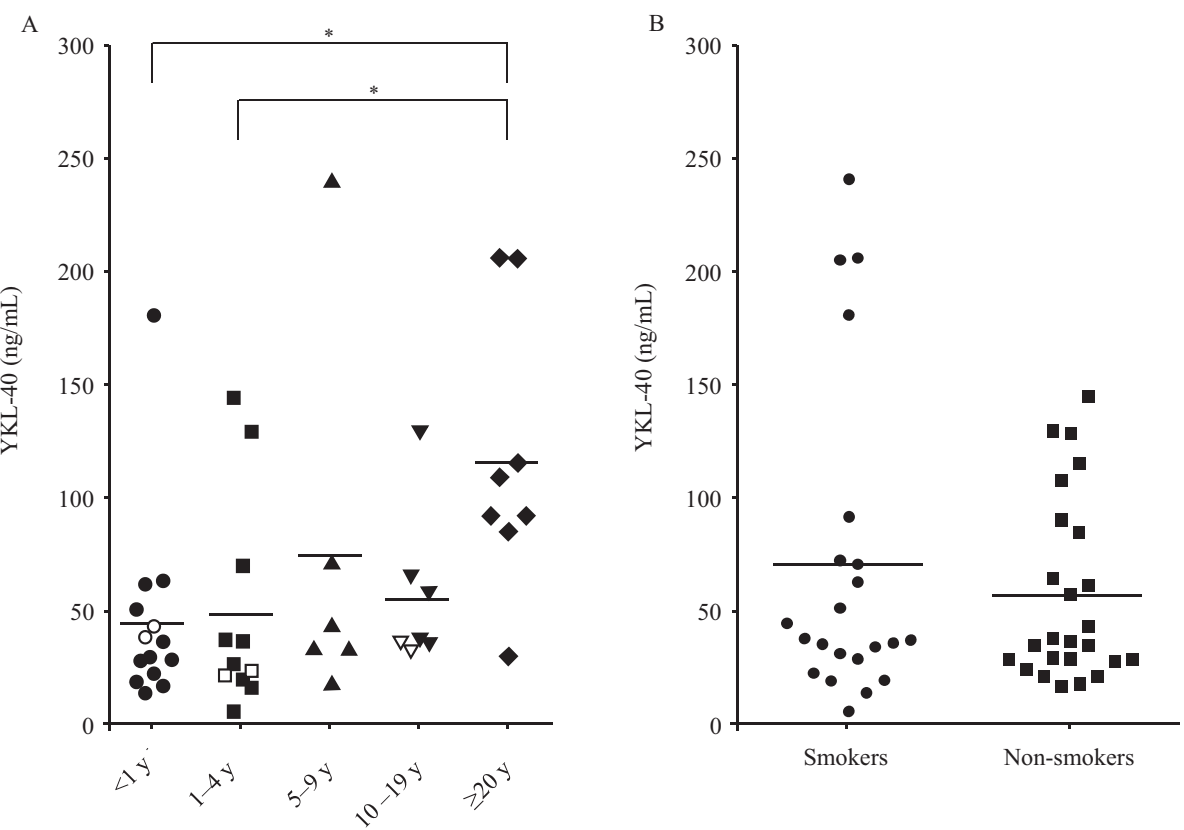

Figure 1. Biological parameter by duration of employment as a snow crab worker and smoking status.

A : YKL-40 levels by employment duration. Circle symbol : subjects with less than 1 year of snow crab worker experience ; square symbol : subjects with 1-4 years ; triangle symbol : subjects with 5-9 years ; inverted triangle symbol : subjects with 10-19 years; diamond symbol: subjects with more than 20 years. Open symbols indicate subjects in each group who experienced wheezes and gave an affirmative response to Q1. Closed symbols indicate subjects in each group who did not experience wheezes and gave a negative response to Q1. Bars represent the mean. Comparisons were made using a Kruskal-Wallis one-way ANOVA test, *p<0.05. B : YKL-40 levels by smoking status. Circle symbol : smoker subjects ; square symbol : non-smokers. Bars represent the mean. Comparisons were made using a $t$-test.

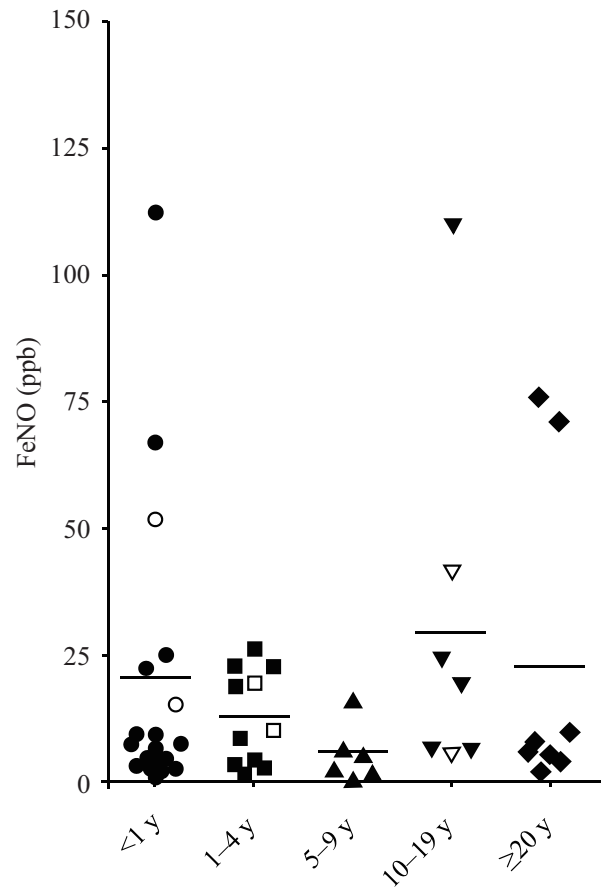

Figure 2. FeNO levels by employment duration.

Circle symbol: subjects with less than 1 year of snow crab processing experience ; square symbol : subjects with 1-4 years ; triangle symbol : subjects with 5-9 years ; inverted triangle symbol: subjects with 10-19 years ; diamond symbol : subjects with more than 20 years. Open symbols indicate the subjects in each group who experienced wheezes and gave an affirmative response to Q1. Closed symbols indicate subjects in each group who did not experience wheezes and gave a negative response to Q1. Bars represent the mean. Comparisons were made using a Kruskal-Wallis one-way ANOVA.

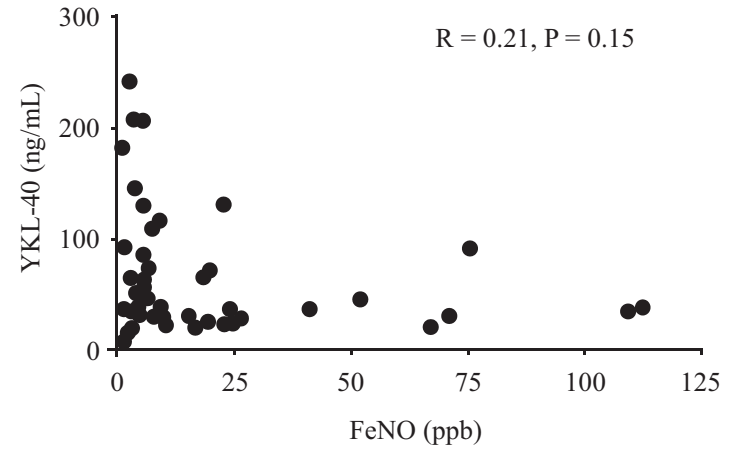

Figure 3. Correlations of serum YKL-40 levels with FeNO levels in all subjects.

Linear regression analysis was used to determine the correlation between serum YKL-40 levels and FeNO levels. Data from 2 of the 49 subjects were excluded because of missing YKL-40 measurements due to blood clotting.

There have been few studies on the prevalence of asthma and asthma symptoms among Asian countries using a standardized questionnaire. Recently, Fukutomi et al. conducted a population-based cross-sectional study of the prevalence of asthma and wheezes by administering the ECRHS questionnaire to Japanese adults (19). They found that the prevalences of asthma and wheezes among Japanese adults aged $27-79$ years were $4.2 \%$ (95\% CI, 9.7 to $10.5 \%$ ) and $10.1 \%$ (95\% CI, 9.7 to $10.5 \%)$, respectively. The prevalences of asthma and wheezes among Japanese snow crab processing workers in this study were higher than those among other Japanese adults. Several studies have demonstrated that snow crab processing workers have a high prevalence of asthma and wheezes in 
Western countries (7-9). The results of this study suggest that the occupational exposure in Japanese harvesting and processing may account for a substantial proportion of asthma experienced by snow crab processing workers.

YKL-40 is a chitinase-like protein that is released from neutrophils and macrophage $(25,26)$. It is involved in inflammation, tissue remodeling, and host defense $(25,26)$. It is also known to increase in the serum and lungs of patients with asthma and is correlated with asthma severity and airway remodeling $(27,28)$. In this study, there were no significant differences between the YKL-40 levels of subjects with and without wheezes. However, twelve subjects in this study (24.5\%) exceeded the mean YKL-40 serum value, which was $36.0 \pm 20.6 \mathrm{ng} / \mathrm{mL}$ in healthy subjects, based on the information from the ELISA kit for YKL-40 (www.RnDSystems.com), plus 2 SDs $(77.2 \mathrm{ng} / \mathrm{mL})$.

Additionally, YKL-40 in subjects who had worked in the industry for more than 20 years was significantly higher than in those who worked in the industry for less than 5 years. Studies have shown that the intensity of exposure according to duration and amount is an important determinant of sensitization and asthma caused by respiratory sensitizers (3). Snow crab is graded as moderate a moderate sensitizer based on evidence from the Royal College of General Practitioners' three-star system for rating OA caused by worksites (29). Snow crab processing plants may present severe enough risk to be able to increase serum YKL-40 levels.

Based on the general recommendations of the recently published ATS Clinical Practice Guideline, if a FeNO-value is below $25 \mathrm{ppb}$, there is thought to be no steroid-sensitive inflammation present (30). In contrast, a value greater than $50 \mathrm{ppb}$ is likely to be associated with steroid-sensitive airway inflammation, which is substantially reflected in eosinophilic airway inflammation (30-32). It is also well acknowledged that smoking reduces FeNO (33). Although five subjects did not experiencing wheezes, based on their questionnaire responses, their FeNO values exceeded $50 \mathrm{ppb}$. This suggests that their airways were inflamed. This inflammation could be associated with environmental exposure from the snow crab processing. Previous studies showed that FeNO did not have any diagnostic value in non-eosinophilic asthma (30-32) ; therefore, when a subject had a FeNO value smaller than $25 \mathrm{ppb}$, we were unable to exclude the presence of asthma.

Both YKL-40 and FeNO are useful biomarkers for asthma. However, the association with YKL-40 and FeNO in asthma remains unclear. This study was unable to find any significant relationship between YKL-40 and FeNO. In subjects who had a FeNO value less than $25 \mathrm{ppb}$, several subjects had high levels of YKL-40. In contrast, with the exception of one subject, all subjects with $>25 \mathrm{ppb}$ in FeNO fell below $77.2 \mathrm{ng} / \mathrm{mL}$ of YKL- 40 . The subjects in the present study can be classified by etiology into three groups : (1) low levels of both YKL-40 and FeNO ; (2) low levels of YKL-40, and high levels of FeNO ; and (3) high levels of YKL-40, and low levels of FeNO. These results may suggest that subjects with high levels of YKL40 differ greatly from those with high levels of FeNO. Further study is needed to investigate the associations between YKL- 40 and FeNO in snow crab workers.

The ECRHS questionnaire does not have a clear definition for current asthma. The studies using this questionnaire used various definitions of the term. The definition of current asthma used in the present study may lead to overdiagnosis, because none of the subjects were under treatment for asthma or other respiratory diseases. Certainly, there was the possibility that the subjects with current asthma had intermittent asthma ; therefore, the definition of current asthma may be fraught with ambiguity. This study estimated the associations of the prevalence of wheezes with employment duration and smoking. Our study was limited by its reliance on a questionnaire to diagnose asthma and asthma-related symptoms. This approach may have led to an overestimation of asthma prevalence.

This study had two major limitations. First, it did not perform immunologic testing such as a skin prick test or an assessment of specific $\operatorname{IgE}$ antibodies to snow crab allergens. A skin prick test carries with it a slight risk of anaphylaxis, so we chose to use a pulmonary function test and FeNO measurements. In addition, we took blood samples at the snow crab processing company. We must avoid taking health risks. We did not have adequate research funds to measure specific IgE antibodies in this study. Previous studies have found that immunological sensitization to snow crab allergens was significantly associated with asthma among snow crab processing workers $(8,10,34)$. Although this study was unable to estimate immunological sensitization to snow crab allergens, it can be said that this type of sensitization may be significantly associated with asthma among Japanese snow crab processing workers.

The second major limitation was the small number of subjects who participated in this study. For the most part, employers were unwilling to cooperate from fear of the occupational exposurerelated health concerns that might be brought to light as a result of our study. Actually, many chief executive officers flatly refused to cooperate with this study. Therefore, it was very difficult to recruit large numbers of subjects. However, as was the case with other studies, this one found that Japanese snow crab processing workers have a relatively high rate of asthma and wheezes compared to other Japanese adults. No other Japanese study has yet investigated the prevalence of asthma among snow crab processing workers. Additionally, as far as we know, this is the first study to assess the levels of fractional exhaled nitric oxide FeNO and YKL-40 among snow crab processing workers. This study may provide fundamental health information regarding OA in Japanese snow crab processing workers.

In conclusion, this cross-sectional study used a Japanese version of the ECRHS questionnaire to determine the prevalences of current asthma and wheezes among Japanese snow crab processing workers. As compared to other Japanese adults, Japanese snow crab processing workers have more than two times the risk of prevalent asthma.

\section{ACKNOWLEDGMENTS}

We would like to thank Esumi (Tokyo, Japan) for their statistical analysis support and Editage (www.editage.jp) for their English language editing.

\section{CONFLICT OF INTEREST}

The authors declare that there are no conflicts of interest regarding the publication of this paper.

\section{AUTHOR CONTRIBUTIONS}

JK, MW, HS, and ES conceived the study. JK, MW, HS, and HK participated in the design. JK and MW collected the data. JK and MW performed the analysis. JK and MW drafted the manuscript. ES contributed to the final approval of the version to be published. All authors had full access to all study data and take full responsibility for the data integrity and analysis accuracy.

\section{REFERENCES}

1. Meredith S, Nordman $\mathrm{H}$ : Occupational asthma : measures of 
frequency from four countries. Thorax $51: 435-40,1996$

2. Mannino DM : How much asthma is occupationally related? Occup Med 15 : 359-368, 2000

3. Mapp CE, Boschetto P, Maestrelli P, Fabbri LM : Occupational asthma. Am J Respir Crit Care Med 172 : 280-305, 2005

4. Blanc PD, Toren K: How much asthma can be attributed to occupational factors? Am J Med 107 : 580-587, 1999

5. Balmes J, Becklake M, Blanc P, Henneberger P, Kreiss K, Mapp CE, Milton D, Schwartz D, Toren K, Viegi G : American Thoracic Society statement : occupational contribution to the burden of airway disease. Am J Respir Crit Care Med 167 : 787-797, 2003

6. Maestrelli P : Natural history of adult-onset asthma : insights from model of occupational asthma. Am J Respir Crit Care Med $169:$ 331-332, 2004

7. Cartier A, Malo JL, Forest F, Lafrance M, Pineau L, St-Aubin JJ, Dubois JY : Occupational asthma in snow crab-processing workers. J Allergy Clin Immunol 74 : 261-269, 1984

8. Gautrin D, Cartier A, Howse D, Horth-Susin L, Jong M, Swanson M, Lehrer S, Fox G, Neis B : Occupational asthma and allergy in snow crab processing in Newfoundland and Labrador. Occup Environ Med 67 : 17-23, 2010

9. Howse D, Gautrin D, Neis B, Cartier A, Horth-Susin L, Jong $\mathrm{M}$, Swanson MC : Gender and snow crab occupational asthma in Newfoundland and Labrador, Canada. Environ Res 101 : 163-174, 2006

10. Cartier A, Malo JL, Ghezzo H, McCants M, Lehrer SB : IgE sensitization in snow crab-processing workers. J Allergy Clin Immunol $78: 344-348,1986$

11. Malo JL, Chrétien P, McCants M, Lehrer S : Detection of snow-crab antigens by air sampling of a snow-crab production plant. Clin Exp Allergy 27 : 75-78, 1997

12. Weytjens K, Cartier A, Malo JL, Chrétien P, Essiembre F, Lehrer S, Swanson M : Aerosolized snow-crab allergens in a processing facility. Allergy 54 : 892-893, 1999

13. Tarlo SM, Balmes J, Balkissoon R, Beach J, Beckett W, Bernstein D, Blanc PD, Brooks SM, Cowl CT, Daroowalla F, Harber P, Lemiere C, Liss GM, Pacheco KA, Redlich CA, Rowe B, Heitzer J : Diagnosis and management of work-related asthma: American College Of Chest Physicians Consensus Statement. Chest $134: 1 \mathrm{~S}-41 \mathrm{~S}, 2008$

14. Baur X, Sigsgaard T, Aasen TB, Burge PS, Heederik D, Henneberger P, Maestrelli P, Rooyackers J, Schlünssen V, Vandenplas O, Wilken D : ERS Task Force on the Management of Work-related Asthma. Guidelines for the management of work-related asthma. Eur Respir J 39 : 529-545, 2012

15. Ohta K, Ichinose M, Nagase H, Yamaguchi M, Sugiura H, Tohda Y, Yamauchi K, Adachi M, Akiyama K: Japanese Society of Allergology. Japanese Guideline for Adult Asthma 2014. Allergol Int 63 : 293-333, 2014

16. Kharitonov SA, Yates D, Robbins RA, Logan-Sinclair R, Shinebourne EA, Barnes PJ : Increased nitric oxide in exhaled air of asthmatic patients. Lancet $343: 133-135,1994$

17. Kim MA, Shin YS, Pham le D, Park HS : Adult asthma biomarkers. Curr Opin Allergy Clin Immunol 14 : 49-54, 2014

18. Lai T, Chen M, Deng Z, L Y, Wu D, Li D, Wu B : YKL-40 is correlated with FEV1 and the asthma control test (ACT) in asthmatic patients : influence of treatment. BMC Pulm Med $15: 1,2015$

19. Fukutomi Y, Nakamura H, Kobayashi F, Taniguchi M, Konno S, Nishimura M, Kawagishi Y, Watanabe J, Komase Y, Akamatsu Y, Okada C, Tanimoto Y, Takahashi K, Kimura T, Eboshida A, Hirota R, Ikei J, Odajima H, Nakagawa T, Akasawa A, Akiyama K : Nationwide cross-sectional population-based study on the prevalences of asthma and asthma symptoms among Japanese adults. Int Arch Allergy Immunol 153 : 280287, 2010

20. de Marco R, Zanolin ME, Accordini S, Signorelli D, Marinoni A, Bugiani M, Lo Cascio V, Woods R, Burney P : A new questionnaire for the repeat of the first stage of the European Community Respiratory Health Survey : a pilot study. Eur Respir J 14 : 1044-8, 1999

21. Watanabe J, Taniguchi M, Takahashi K, Nakagawa T, Ooya Y, Akazawa A, Akiyama K : Validation of ECRHS Questionnaire in Japanese to use for nation-wide prevalence study of adult asthma (in Japanese). Arerugi 55 : 1421-1428, 2006

22. Janson C, Chinn S, Jarvis D, Burney P : Physician-diagnosed asthma and drug utilization in the European Community Respiratory Health Survey. Eur Respir J 10 : 1795-1802, 1997

23. American Thoracic Society, European Respiratory Society : ATS/ERS recommendations for standardized procedures for the online and offline measurement of exhaled lower respiratory nitric oxide and nasal nitric oxide, 2005. Am J Respir Crit Care Med 171 : 912-930, 2005

24. Global Initiative for Asthma (GINA). Global strategy for asthma management and prevention 2014 (revision). Bethesda : National Institutes of Health, 2014

25. Volck B, Price PA, Johansen JS, Sørensen O, Benfield TL, Nielsen HJ, Calafat J, Borregaard N : YKL-40, a mammalian member of the chitinase family, is a matrix protein of specific granules in human neutrophils. Proc Assoc Am Physicians $110: 351-360,1998$

26. Kirkpatrick RB, Emery JG, Connor JR, Dodds R, Lysko PG, Rosenberg $\mathrm{M}$ : Induction and expression of human cartilage glycoprotein 39 in rheumatoid inflammatory and peripheral blood monocyte-derived macrophages. Exp Cell Res 237 : 46-54, 1997

27. Kim MA, Shin YS, Pham le D, Park HS : Adult asthma biomarkers. Curr Opin Allergy Clin Immunol 14 : 49-54, 2014

28. Rathcke CN, Vestergaard H : YKL-40, a new inflammatory marker with relation to insulin resistance and with a role in endothelial dysfunction and atherosclerosis. Inflamm Res $55: 221-227,2006$

29. Baur X : A compendium of causative agents of occupational asthma. J Occup Med Toxicol. $2013 ; 8$ : 15, 2013

30. Dweik RA, Boggs PB, Erzurum SC, Irvin CG, Leigh MW, Lundberg JO, Olin AC, Plummer AL, Taylor DR: American Thoracic Society Committee on Interpretation of Exhaled Nitric Oxide Levels (FENO) for Clinical Applications. An official ATS clinical practice guideline : interpretation of exhaled nitric oxide levels (FENO) for clinical applications. Am J Respir Crit Care Med 184 : 602-615, 2011

31. Barnes PJ, Dweik RA, Gelb AF, Gibson PG, George SC, Grasemann H, Pavord ID, Ratjen F, Silkoff PE, Taylor DR, Zamel $\mathrm{N}$ : Exhaled nitric oxide in pulmonary diseases : a comprehensive review. Chest 138 : 682-692, 2010

32. Schneider A, Faderl B, Schwarzbach J, Welker L, KarschVölk M, Jörres RA : Prognostic value of bronchial provocation and FENO measurement for asthma diagnosis-results of a delayed type of diagnostic study. Respir Med 108:34-40, 2014

33. Kharitonov SA, Robbins RA, Yates D, Keatings V, Barnes PJ : Acute and chronic effects of cigarette smoking on exhaled nitric oxide. Am J Respir Crit Care Med 152 : 609-612, 1995

34. Bønløkke JH, Gautrin D, Sigsgaard T, Lehrer SB, Maghni K, Cartier A : Snow crab allergy and asthma among Greenlandic workers-a pilot study. Int J Circumpolar Health $71: 19126$, 2012 